\title{
Reference ranges of lymphocyte subsets in healthy Qatari adults
}

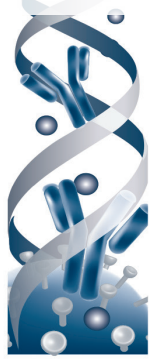

\begin{abstract}
Aim: Determine reference ranges of lymphocyte subsets in healthy Qatari adults. Patients \& Methods: Blood samples $(n=150)$ were investigated using four colors flow cytometery. Results: The mean percentage and absolute values of the lymphocyte

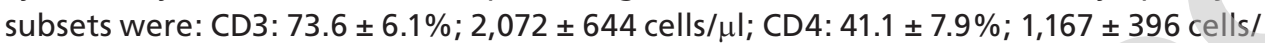
$\mu \mathrm{l} ; \mathrm{CD} 8: 33.8 \pm 7.1 \% ; 967 \pm 364$ cells $/ \mu \mathrm{l} ; \mathrm{B}$ cells $(\mathrm{CD} 19+): 11.3 \pm 3.9 \% ; 318 \pm 144 \mathrm{cells} / \mu \mathrm{l}$ and natural killer (NK) cells (CD16/56+): $16.5 \pm 6.3 \%, 440 \pm 401$ cells/ $\mu \mathrm{l}$, respectively. The CD4/CD8 ratio was $1.3 \pm 0.5$. The ratio, CD3+ and CD4+ percentage and CD4+ cell counts were significantly higher in females; CD8+ and NK cell count and CD8+ percentage were significantly higher in males. The impact of age was less certain. Conclusion: The reference values of lymphocyte subsets appear to be specific to this population, demonstrating the importance of establishing local reference ranges.
\end{abstract}

Keywords: B cells $\bullet$ CD3 $\bullet$ CD4 $\bullet$ CD8 $\bullet$ flow cytometry $\bullet$ lymphocyte subsets $\bullet$ natural killer cells $\bullet$ reference ranges,

\section{Introduction}

Lymphocyte immunophenotyping by flow cytometry is an important tool in differential diagnosis of congenital and acquired immune deficiencies, lymphoproliferative disorders and acute leukemias [1]. In addition, it is used for monitoring treatment response and disease progression with anti-retroviral and immunosuppressive therapy. Various studies suggest that lymphocyte subsets reference ranges are influenced by age, sex, ethnicity, and environment [2-5]. The variations in the values of the lymphocyte subsets emphasize the importance of establishing local reference ranges to allow for meaningful comparisons and accurate interpretation of immunophenotyping data across different cultures and ethnic groups. Lifestyle factors, e.g. smoking, have also been shown to influence lymphocyte subset values [6,7].

Indeed, reference range for peripheral blood lymphocyte subsets have been established in many studies across different countries, revealing variations in the normal range for lymphocyte subsets according to age, sex, race, and environmental factors [3,4,8-16]. Establishment of an internal normal range of lymphocyte subsets is a important for each population considering the effect of environmental factors, age, ethnical diversity on the immune system. Hence, this study aims to determine the laboratory reference ranges for lymphocyte subsets in healthy Qatari adults using flow cytometry.

This article reports the local reference range for peripheral blood lymphocyte subsets, both percentages and absolute counts, in a representative sample of 150 healthy adult Qatari population.

The results have been stratified by age, sex, and smoking status. The population selected is largely homogenous (100\% Qatari Arabs) so effect of race was not investigated. The results are briefly compared with other population data from published studies.

\section{Materials \& methods \\ Subjects}

A total of 150 healthy Qatari volunteers (18-55 yr old; all Qatari Arabs) were recruited for the study from September 2013 to March
Asma Al-Thani ${ }^{*}$, , Wedad $\mathrm{H}$ Saleem ', Asma Al-Marwani², Adel Alnaqdy ${ }^{3}$ \& Hend Sharafeldin ${ }^{4}$

${ }^{1}$ Health Sciences Department, College of Arts \& Sciences, Qatar University, Doha, Qatar

${ }^{2}$ Hematology Department, Hamad General Hospital, Hamad Medical Corporation, Doha

${ }^{3}$ Immunolgy Department, Hamad General Hospital, Hamad Medical Corporation, Doha

${ }^{4}$ Laboratory Department, Qatar Armed Forces Medical Services, Doha, Qatar

*Author for correspondence:

Tel.: +974 44034800

Fax: +974 44034801

aaja@qu.edu.qa 
2014. The authors aimed to recruit a maximum of 150 for this study, is realistic goal over the study period in a total population of approximately 300,000 . The subpopulation evaluation was not powered to determined statistical differences due to the low number of the overall study population so the results would have to be interpreted with caution.

The Participants were screened initially with a health questionnaire that sought to identify and exclude those who had recent infections, recent vaccinations (within the past 4 weeks), any significant medical illnesses, or use of long-term medications. Subjects were also required to have their complete blood cell count (CBC) checked using the Beckman Coulter Hematology Analyzer. Participants with abnormal $\mathrm{CBC}$ participants were excluded from the study. Normal CBC ranges constituted: white blood cells (WBC) count 4-10 $\mathrm{x} 109 / \mathrm{l}$; hemoglobin range in men: $13-17 \mathrm{~g} / \mathrm{dl}$, and for women: $11.5-15 \mathrm{~g} / \mathrm{dl}$; platelets $150-450 \times 109 / 1$.

A signed consent form was obtained from all participants.

\section{Blood collection}

Whole blood was collected into EDTA Vacutainer tubes. The blood samples were transported to the laboratory and stained using BD Multitest IMK Kit with BD Trucount ${ }^{\mathrm{TM}}$ tubes (Cat. No. 340504, BD Bioscience, San Jose, CA, USA) within 24 h of collection. Samples were checked for clots or hemolysis formation before analysis.

\section{Flow cytometry analysis}

Lymphocyte subsets were analyzed on BD LSRFortessa $^{\mathrm{TM}}$ flow cytometer (BD Bioscience). Antibodies to identify the lymphocytes were chosen to include the following: FITC-labeled CD3, CD8 phycoerythrin

Table 1. Baseline demographics of the the study population $(n=150)^{\dagger}$.

\begin{tabular}{|ll|}
\hline Total $(\mathrm{n})$ & 150 \\
\hline Median Age & 29 (range; $18-55$ years) \\
\hline Males & 96 \\
\hline Females & 54 \\
\hline Smokers & 36 \\
\hline Non-smokers & 114 \\
\hline$\leq 45$ years & 135 (91 males; 44 females) \\
\hline$<25$ years & 43 (33 males; 10 females) \\
\hline $25-35$ years & 57 (45 males; 12 females) \\
\hline $35-45$ years & 35 (11 males; 24 females \\
\hline$\geq 45$ years & 15 (5 males; 10 females) \\
\hline${ }^{\dagger}$ All subjects were Qatari Arabs. \\
\hline
\end{tabular}

(PE), CD45 peridinin chlorophyllprotein (PerCP), and CD4 allophycocyanin (APC); PE-labeled CD16, and CD56, PerCP-labeled CD45 and APC-labeled CD19.

Gating the lymphocytes was based on CD45 versus side scatter analysis (SSC); and lymphocyte subpopulations were further analyzed from within this gate. The percentages of $\mathrm{T}$ and $\mathrm{B}$ lymphocytes were determined using quadrant statistics from dot plots of CD8 versus $\mathrm{CD} 4$ for suppressor/cytotoxic $(\mathrm{CD} 3+\mathrm{CD} 8+)$ and helper/inducer (CD3+CD4+) T-lymphocytes; and $\mathrm{CD} 16+\mathrm{CD} 56$ vs CD19 dot plots for B (CD19+) and natural killer (NK) cells (CD3-CD16+ or CD56+ or both) cells.

For the absolute number, a known volume of the sample was stained directly in a BD Trucount tube. The lyophilized pellet in the tube dissolved, releasing a known number of fluorescent beads. The absolute number $($ cells $/ \mu \mathrm{l})$ of positive cells in the sample was then determined by comparing cellular events to bead events using the following formula:

Absolute Cell Count $=$ (number of target population events / number of bead events collected) $\times$ (number of beads per test from the package insert / test volume of $50 \mu \mathrm{l}$ )

The percentage was calculated from the percentage of positive cells per lymphocyte population.

BD Multi-Check ${ }^{\mathrm{TM}}$ control (BD Catalog Nos. 340911) and the BD Multi-Check CD4 Low control (BD Catalog Nos. 340914) were used as procedural controls and were processed similarly to the test samples to monitor the outgoing performance of the analytic process. A performance check (CS\&T) application in BD FACSDivaTM software was running using BD ${ }^{\mathrm{TM}}$ Cytometer Setup and Tracking (CS\&T) Bead to monitor performance on a daily basis and to optimize laser delay

\section{Statistical analysis}

Data were analyzed using BD FACSDiva ${ }^{\mathrm{TM}}$ software 6.0. The results were reported as the percentage of positive cells per lymphocyte population or as the number of positive cells per microliter of blood (absolute count). The absolute numbers were not compared.

All data was analyzed using StatPlus ${ }^{\circledR}$ statistics software version 5.8.0.0. The distribution of T-cell subsets was compared between groups using the student t- test and $\mathrm{p}$ - values of $<0.05$ were considered significant.

\section{Results}

\section{Subjects}

A total of 150 healthy Qatari adults ranging in age from 18 to 55 years were included in the study. The baseline demographics of the subjects are shown in Table 1. 
(A)

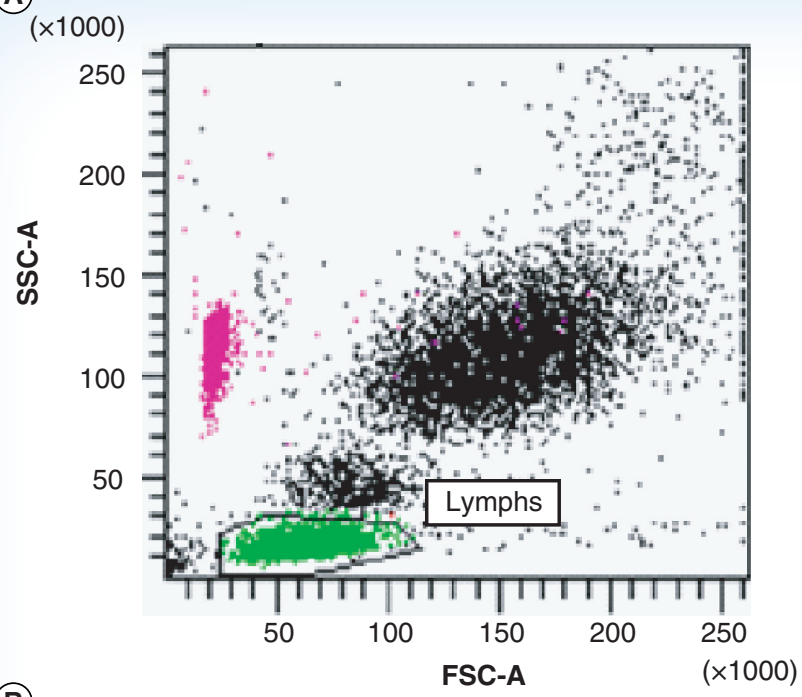

$(\times 1000)$

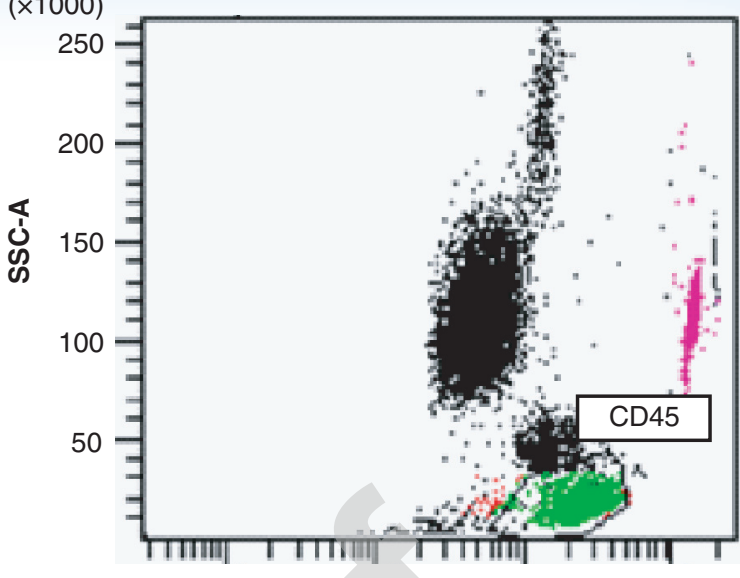

$10^{2}$ $\begin{array}{lr}10^{3} & 10^{4} \\ \text { CD45 PerCP-A }\end{array}$

(B)

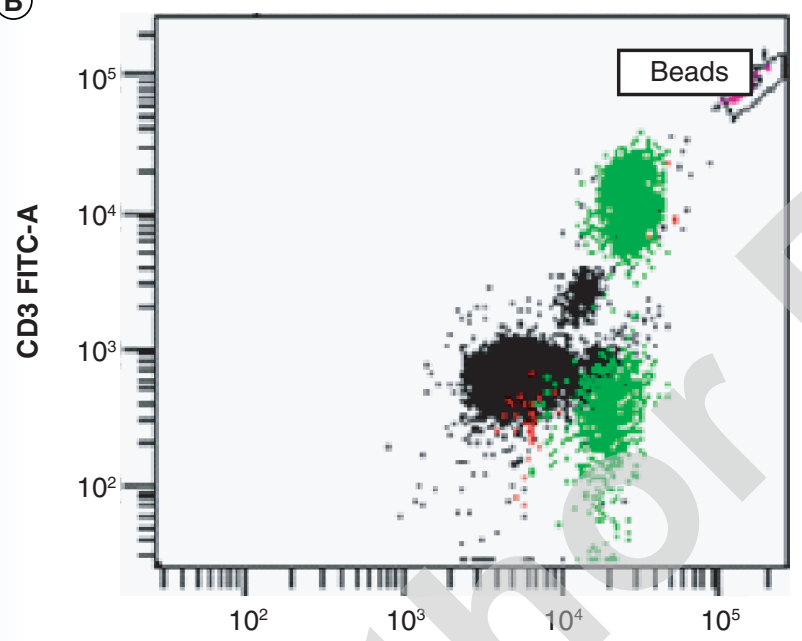

(C)
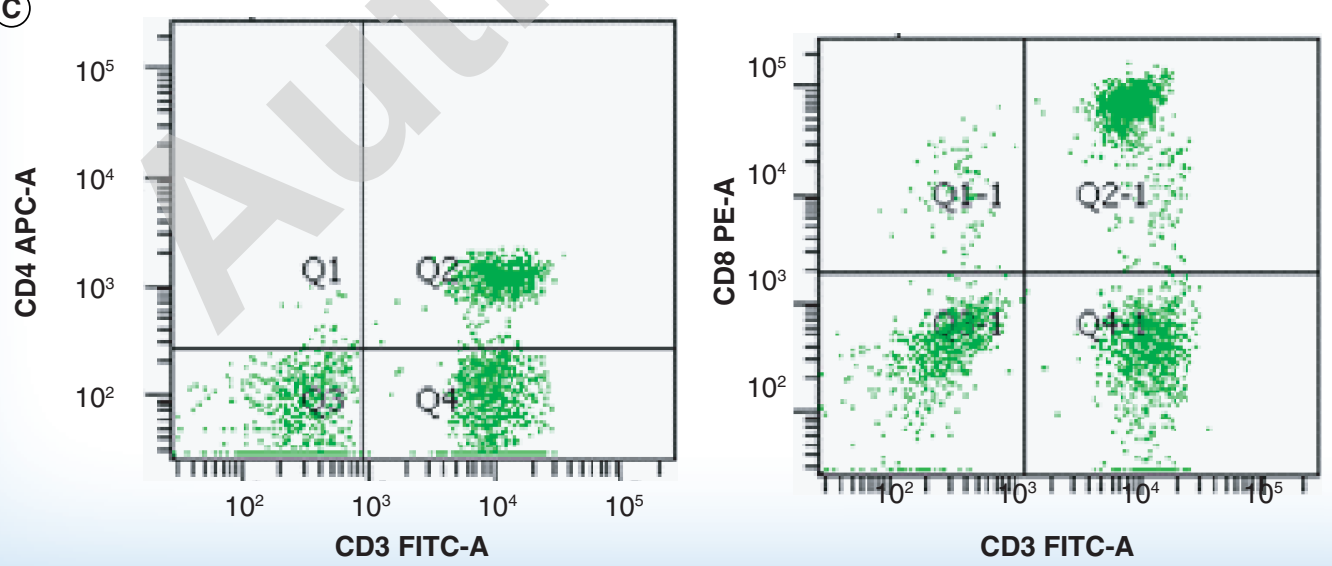

Figure 1. Examples of dot plots of flow cytometry data.(A) The CD45 vs SSC dot plot. The Gated lymphocyte population appeared as a bright, compact cluster with low SSC. Monocytes and granulocytes should also appeared as distinct clusters. (B) Gating of BD Trucount bead to identify BD Trucount absolute count bead events. (C) CD3 vs CD4 plot (left figure) and the right figure CD3 vs CD8, where Q2 is the percentage of CD3+CD4+ cells and Q2-1 is the percentage of CD3+CD8+ cells. (D) Dentification of suppressor/cytotoxic (CD3+CD8+) (Q1-2) and helper/inducer (CD3+ CD4 +) (Q4-2) lymphocytes in CD8 vs CD4 dot plot. (E) CD3 vs CD19 plot (left figure) and the right figure $C D 3$ vs $C D 16+C D 56$, where $Q 1$ is the percentage of $C D 3-C D 19+$ (Bcells) and $Q 1-1$ is the percentage of CD3-CD16+CD56+ (natural killer cells). (F) Identification of B (CD19+) and NK (CD3-CD16+ or CD56+ or both) lymphocytes in CD16 + CD56 vs CD19 dot plot. SSC: Side scatter. 


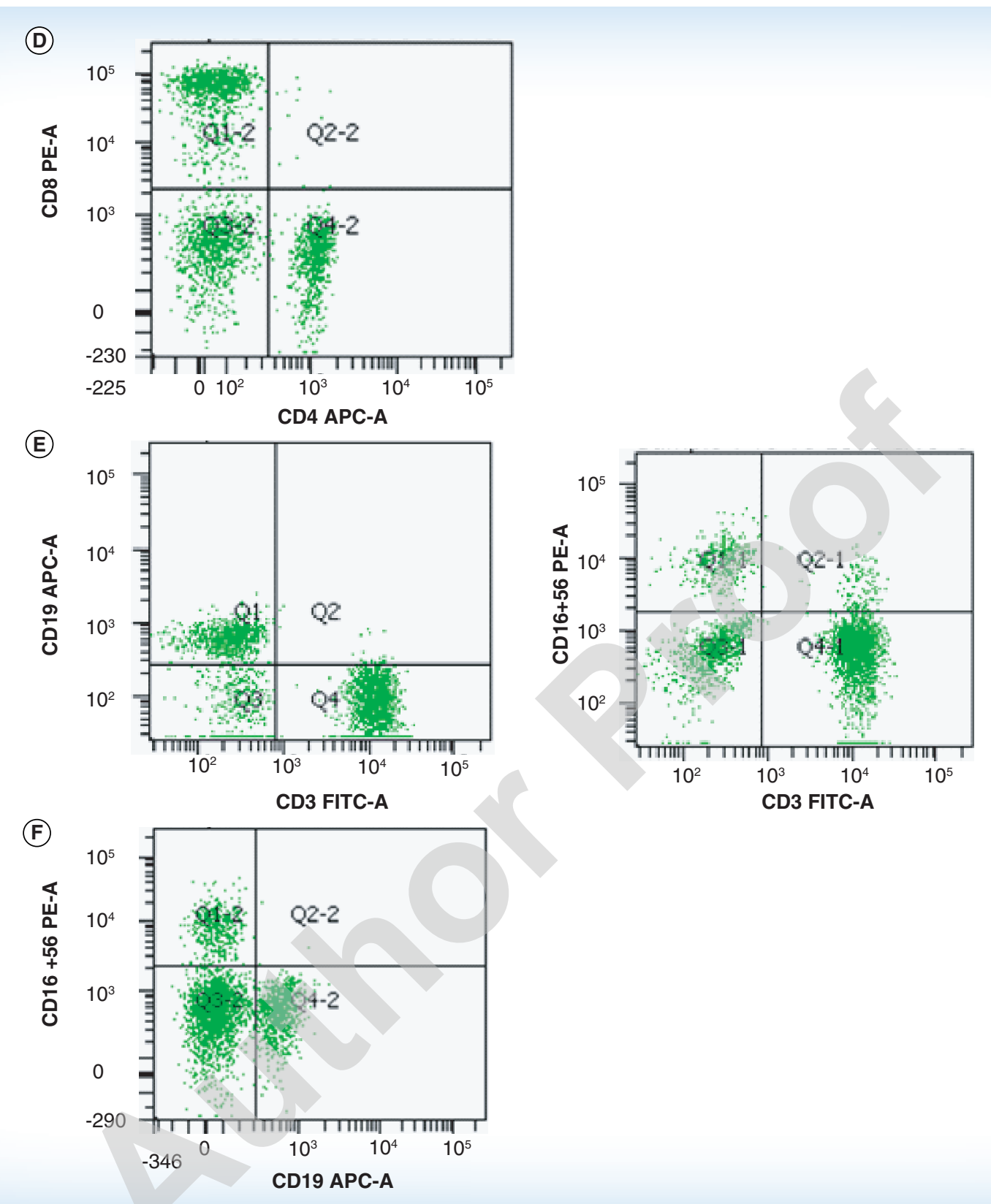

Figure 1. Examples of dot plots of flow cytometry data (cont.).(A) The CD45 vs SSC dot plot. The Gated lymphocyte population appeared as a bright, compact cluster with low SSC. Monocytes and granulocytes should also appeared as distinct clusters. (B) Gating of BD Trucount bead to identify BD Trucount absolute count bead events. (C) CD3 vs CD4 plot (left figure) and the right figure CD3 vs CD8, where Q2 is the percentage of CD3+CD4+ cells and Q2-1 is the percentage of CD3+CD8+ cells. (D) Dentification of suppressor/cytotoxic $(C D 3+C D 8+)(Q 1-2)$ and helper/inducer (CD3+ CD4 +) (Q4-2) lymphocytes in CD8 vs CD4 dot plot. (E) CD3 vs CD19 plot (left figure) and the right figure $C D 3$ vs CD16+CD56, where Q1 is the percentage of CD3-CD19+ (Bcells) and Q1-1 is the percentage of CD3-CD16+CD56+ (natural killer cells). (F) Identification of B (CD19+) and NK (CD3-CD16+ or CD56+ or both) lymphocytes in CD16 + CD56 vs CD19 dot plot. SSC: Side scatter.

\section{Flow cytometry}

Figure 1 summarizes examples of dot plots of flow cytometry data. Total $\mathrm{T}$ cells were selected through $\mathrm{CD} 3+$ expression; $\mathrm{T}$ cells $(\mathrm{CD} 3+)$ were then divided into CD4+ (helper;) and CD8+(cytotoxic) populations; NK cells and B cells were also selected through expression of CD16/56+ and CD19+, respectively.
The absolute and percentage values of these cells were then determined. Table 2 demonstrates the reference ranges of lymphocyte subsets of the study population $(\mathrm{n}=150)$.

When the reference ranges found in this study were compared with the reference ranges of the $\mathrm{BD}$ Multitest IMK Kit, significant differences were found (Table 3). 


\begin{tabular}{|c|c|c|c|c|}
\hline Cell type & $\begin{array}{l}\text { Percentage } \% \\
\text { mean } \pm \text { SD }\end{array}$ & $\begin{array}{l}\text { Reference } \\
\text { range } 95 \% \mathrm{Cl}\end{array}$ & $\begin{array}{l}\text { Absolute cell count / } \\
\mu l \text { mean } \pm S D\end{array}$ & $\begin{array}{l}\text { Reference range } 95 \% \\
\mathrm{Cl}\end{array}$ \\
\hline $\mathrm{CD} 3+$ & $73.6 \pm 6.1$ & $56.5-92.6$ & $2072 \pm 644$ & $792-3722$ \\
\hline CD4+ & $41.1 \pm 7.9$ & $22.7-61.8$ & $1167 \pm 396$ & $546-2591$ \\
\hline CD8+ & $33.8 \pm 7.1$ & $19.8-55.5$ & $967 \pm 364$ & $375-2532$ \\
\hline B cells & $11.3 \pm 3.9$ & $1.7-23.9$ & $318 \pm 144$ & $43-750$ \\
\hline Natural killer cells & $16.5 \pm 6.3$ & $4.4-35.1$ & $440 \pm 401$ & 103-1194 \\
\hline CD4/CD8 ratio (range) & $1.3 \pm 0.5(0.4-3.3)$ & & & \\
\hline
\end{tabular}

\section{Effects of sex \& age}

The data were further analyzed according to sex and age. The reference ranges for males and females are tabulated in Table 4. The percentage of CD3 + T cells was significantly higher in females compared with males ( 75.3 vs $71.9 \% ; \mathrm{p}<0.001)$; The percentage and absolute count values of $\mathrm{CD} 4+$ cells of females were also significantly higher compared with males ( 45.5 vs $38.0 \%, p=0.000$; 1256 cells/ $\mu \mathrm{l}$ vs 1130 cells $/ \mu \mathrm{l}, \mathrm{p} \leq 0.05$, respectively). The percentage and absolute count of CD8 + cells were significantly higher in males compared with females (35.6 vs $30.8 \%, \mathrm{p}<0.001 ; 1079$ cells/ $\mu \mathrm{l}$ vs. 855 cells $/ \mu \mathrm{l}, \mathrm{p}<$ 0.001 , respectively). The absolute number of NK cells was significantly lower in females compared with males ( 403 cells $/ \mu \mathrm{l}$ vs 514 cells $/ \mu 1 ; \mathrm{p}<0.02$ ). There were no significant differences in the percentage and absolute count of $\mathrm{B}$ cell between males and females. The CD4/CD8 ratio was significantly higher in females compared with male ratios (1.1 vs $1.5 ; \mathrm{p}<0.0001$ ) (Table 4).

In terms of age, 15 subjects were $\geq 45$ years and 135 were $\leq 45$ years old. Comparison of the reference ranges of lymphocytes subsets between the two groups is summarized in Table 5.

The percentage values of $\mathrm{CD} 3+$ and $\mathrm{CD} 4+$ cells as well as CD4/DC8 ratio were significantly increased in $\geq 45$ years old group compared with $\leq 45$ years old group. Conversely, there were significant decreases in absolute count of $\mathrm{CD} 8+$ and in absolute count and percentage of $B$ cells in the $\geq 45$ years old group comparing with $\leq 45$ years old group. However, No significant differences in the NK cells between the two groups.

\section{Effect of smoking}

The lymphocyte subset percentages and absolute values were compared between smokers $(n=36)$ and non-smokers $(n=114)$. There were no significant differences in the percentages or absolute count values of lymphocyte subsets between smokers and non-smokers (data not shown). When this analysis was applied to just the male population (as there were no female smokers in our study), the same non-significant results were obtained (data not shown).

\section{Discussion}

In this study, we aimed to obtain reference ranges for lymphocyte subsets representative of the adult population in Qatar. The reference ranges identified are applicable to patients between $18-55$ years of age. As far as we know, this is the first study that uses the flow

\begin{tabular}{|c|c|c|c|c|c|}
\hline \multirow[t]{2}{*}{ Cell type } & \multicolumn{2}{|c|}{$\begin{array}{l}\text { Present Study } \\
\qquad(n=150)\end{array}$} & \multicolumn{2}{|c|}{$\begin{array}{l}\text { Representative reference ranges for BD } \\
\text { Multitest }(15)+(n=164)\end{array}$} & \multirow[t]{2}{*}{$P$ value } \\
\hline & Mean (\%) & $\begin{array}{l}\text { Reference range } \\
(\%)\end{array}$ & Mean (\%) & Reference range (\%) & \\
\hline CD3 & 73.6 & $56.7-92.6$ & 72 & $56-86$ & NS \\
\hline CD4 & 41.1 & 22.7- 61.8 & 45 & $33-58$ & $<0.0001$ \\
\hline CD8 & 33.8 & $19.8-55.5$ & 24 & $13-39$ & $<0.0001$ \\
\hline B cells & 11.3 & $1.7-23.9$ & 14 & $5-22$ & $<0.0001$ \\
\hline NK & 16.5 & 4.4- 35.1 & 13 & $5-26$ & $<0.0001$ \\
\hline
\end{tabular}


Table 4. Lymphocyte subset percentages and absolute-number reference ranges for males and females in the study population $(n=150)$.

\begin{tabular}{|c|c|c|c|c|c|c|}
\hline Cell type & \multicolumn{2}{|c|}{ Male $(n=96)$} & \multicolumn{2}{|c|}{ Female $(n=54)$} & \multicolumn{2}{|c|}{ P value } \\
\hline CD4+ & $1130(546-2135)$ & $38.0(21.2-64.1)$ & $1256(548-2592)$ & $45.5(28-61.8)$ & $\leq 0.05$ & $<0.00001$ \\
\hline $\mathrm{CD} 8+$ & $1079(376-2532)$ & $35.6(19.3-58.9)$ & $855(300-1813)$ & $30.8(19.8-41.6)$ & $=0.001$ & $<0.001$ \\
\hline $\begin{array}{l}\text { Natural } \\
\text { killer cells }\end{array}$ & $514(148-2383)$ & $17.1(6.0-44.0)$ & 403 (103-1195) & $15.0(4.4-32.3)$ & $<0.02$ & NS \\
\hline $\begin{array}{l}\mathrm{CD} 4 / \mathrm{CD} 8 \\
\text { ratio }\end{array}$ & $1.2(0.37-3.3)$ & & $1.5(0.70-2.8)$ & & $<0.0001$ & \\
\hline
\end{tabular}

cytometry method to establish lymphocyte subsets reference ranges in the Qatari population

Applicable flow cytometric analysis depends on the of reference values, which are subject to variation depending on various factors such as age and sex $[17,18]$. This variation suggests that each population should have its own lymphocyte subset reference ranges. Establishment of local reference ranges is important for interpretation of laboratory results [19].

In this study, the mean absolute number and percentage value of CD4+, CD8+, CD 19+ (B cells) and NK cells were significantly higher than the reference ranges of BD Multitest IMK Kit, suggesting a higher range for the Qatari population compared with the American Caucasian population [15].

Furthermore, the results obtained from our population were found to be different from that of other populations studied from published literature (Table 6). The absolute count of CD3, CD4, CD8 and NK cells in the Qatari adult population was markedly higher compared with those in the published studies. However, there appeared to be little difference in the absolute count of CD19 cells in our study compared with Kuwaiti, Dutch and Chinese studies. Overall, the Kuwaiti population study had reference ranges most comparable to our study (though there was still a large difference seen). This further confirms that each population does indeed need to establish their own reference ranges. Table 6 summarizes the comparison between lymphocyte subsets in this study compared with other population data.

It is important to note here that the Qatar population was composed predominately of young individuals $(\leq 45 \mathrm{yr})$. The frequencies of lymphocytes in the older subjects in the Qatar group are more similar to the reference ranges reported in the literature than the younger Qatar subjects. The variation observed in this study may be accounted by the fact that here we stud-

Table 5. Lymphocyte subset percentages and absolute-number reference ranges for $\leq 45 \mathrm{yr}$ and $\geq 45 \mathrm{yr}$ old in the total study population $(n=150)$.

\begin{tabular}{|c|c|c|c|c|c|c|}
\hline \multirow[t]{2}{*}{ Cell type } & \multicolumn{2}{|c|}{$\begin{array}{l}\geq 45 \text { years }(n=15) \\
\text { Mean }(95 \% \text { Range })\end{array}$} & \multicolumn{2}{|c|}{$\begin{array}{l}\leq 45 \text { years }(n=135) \\
\text { Mean }(95 \% \text { range })\end{array}$} & \multicolumn{2}{|c|}{$P$ value } \\
\hline & $\begin{array}{l}\text { Absolute count } \\
\text { (range) }\end{array}$ & $\begin{array}{l}\text { \% Percentage } \\
\text { (range) }\end{array}$ & $\begin{array}{l}\text { Absolute count } \\
\text { range) }\end{array}$ & $\begin{array}{l}\text { \% Percentage } \\
\text { (range) }\end{array}$ & $\begin{array}{l}\text { Absolute } \\
\text { count }\end{array}$ & $\begin{array}{l}\text { Percentage } \\
(\%)\end{array}$ \\
\hline CD3+ & $1900(1160-2704)$ & 77 (60.3-92.6) & 2173 (793-3993) & $72.7(56.7-86.9)$ & NS & $<0.02$ \\
\hline CD4+ & $1227(848-1596)$ & $48.8(36.6-64.1)$ & 1169 (546-2592) & $39.8(21.2-61.8)$ & NS & $<0.0001$ \\
\hline CD8+ & $781(428-1293)$ & $30.6(19.3-42.9)$ & $1022(300-2532)$ & $34.3(19.8-58.9)$ & $<0.05$ & NS \\
\hline CD19+ & $213(43-495)$ & $8.5(5.5-24.3)$ & $341(51-772)$ & $11.8(5.5-24.3)$ & $<0.01$ & $<0.01$ \\
\hline NK & $386(183-802)$ & $15.9(7.3-32.3)$ & $484(103-2382)$ & $16.4(4.4-44.0)$ & NS & NS \\
\hline $\begin{array}{l}\mathrm{CD} 4 / \mathrm{CD} 8 \\
\text { ratio }\end{array}$ & $1.7(1.0-3.3)$ & & $1.3(0.4-2.8)$ & & $<0.01$ & \\
\hline
\end{tabular}


Table 6. Comparison of lymphocyte subsets reference range of the present study with other reference ranges.

\begin{tabular}{|c|c|c|c|c|c|}
\hline Qatar $(n=150)$ & $\mathrm{CD} 3+$ & CD4+ & CD8+ & CD19+ & $\begin{array}{l}\text { Natural killer } \\
\text { cells }\end{array}$ \\
\hline \multicolumn{6}{|l|}{ Absolute count/ $\mu /$} \\
\hline Mean $\pm(S D)$ & $2142(676)$ & 1165 (396) & $967(364)$ & $319(144)$ & $498(401)$ \\
\hline Median & 2009 & 1109 & 940 & 307 & 411 \\
\hline 95\% Range & $792-3991$ & $546-2591$ & $300-2532$ & 43-771 & $103-2382$ \\
\hline \multicolumn{6}{|l|}{ Percentage \% } \\
\hline Mean $\pm(S D)$ & $73.2(6.5)$ & $40.6(8.1)$ & $33.9(7.6)$ & $11.5(4.3)$ & $16.4(7.0)$ \\
\hline Median & 73.6 & 40.2 & 33 & 10.7 & 15.1 \\
\hline 95\% Range & $57-92.6$ & $21.2-64.1$ & $19.3-58.9$ & $1.7-24.3$ & 4.4-44 \\
\hline \multicolumn{6}{|l|}{ Kuwait (22) $(n=127)$} \\
\hline Absolute count/ $\mu$ l‡ & $1779(470)$ & $1059(300)$ & $739(220)$ & $339(140)$ & $329(130)$ \\
\hline \multicolumn{6}{|l|}{ Oman $(40)(n=50)$} \\
\hline Percentaget & $76.5(8)$ & $45(6.8)$ & $29.5(6)$ & $14(4.3)$ & $7(4.3)$ \\
\hline \multicolumn{6}{|c|}{ Caucasian $(12)(n=271)$} \\
\hline Percentage \%* & $73(6.2)$ & $43(7.5)$ & $33(7.5)$ & $14(4.2)$ & $14(6.1)$ \\
\hline \multicolumn{6}{|l|}{ Dutch $(41) \S(n=1365)$} \\
\hline Absolute count/ $\mu$ l‡ & $1525(458)$ & $993(319)$ & $506(220)$ & $313(147)$ & NA \\
\hline \multicolumn{6}{|c|}{ Switzerland $(42)(n=70)$} \\
\hline Absolute count/ $\mu \mathrm{lt}$ & $1075(313)$ & $691(208)$ & 347 (172) & $170(97)$ & $183(116)$ \\
\hline \multicolumn{6}{|l|}{ Ethiopia (41) (n=142) } \\
\hline Absolute count/ $\mu$ l‡ & $1555(463)$ & $775(225)$ & $747(333)$ & $191(94)$ & 250 (137) \\
\hline \multicolumn{6}{|l|}{ China (43) $(n=273)$} \\
\hline Absolute count/ $\mu \mathrm{lt}$ & $1362(382)$ & $760(233)$ & $515(192)$ & $298(124)$ & $229(132)$ \\
\hline $\begin{array}{l}\text { Values given are mean } \pm(S \text {. } \\
\text { Values given are median } \pm(S \\
\text { Percentage values not avail } \\
\text { Dutch samples were contro } \\
\text { NA: Not available; NS: Not }\end{array}$ & ed. & & & & \\
\hline
\end{tabular}

ied younger subjects than were studied in the reference ranges reported in the literature. A larger study with more balanced numbers of individuals under and over 45 years of age is needed to verify this.

In our study, significant increases were observed in the mean absolute numbers and percentages of CD3+ and CD4 + cells in females compared with males. Conversely, there were increases in the mean absolute number and percentage of $\mathrm{CD} 8+$ and NK cells in males compared with females. In the literature, some studies have reported higher values of $\mathrm{CD} 3+$ and $\mathrm{CD} 4+$ cells in females compared with males $[2,11,12,16,20]$, while other studies report no difference between the two sexes $[11,21,22]$. Significantly lower NK values have also been reported in women vs. men [11,23].

The differences observed may be the result of hormonal differences between genders as seen in studies in mice $[24,25]$. The mechanism may involve androgens' effect on thymocytes, mediating the process of thymocyte selection, with the potential to impart gender-specific characteristics on the peripheral $\mathrm{T}$ cell repertoire $[25,26]$.

While variable results have been reported in humans and mice regarding levels of NK and B cells, most of these studies described declining levels of these cells with aging [27-31]. With respect to T-cells, however, although some studies have reported changes in $\mathrm{T}$ cell levels, especially a decrease in the CD8 cells with increasing age [2,10,11,32-34], other (older) have reported increase in CD4+ and /or CD8+ [24,35,36]. The impact of age on lymphocyte subsets is not well established, with contradictory results from various studies. The inconsistency across published literature may be due to the fact that different studies compared different age 
ranges of subjects. In our study we observed significant changes of $\mathrm{T}$ lymphocytes as well as $\mathrm{B}$ cells with ageing. Our data showed significant increase in CD3+, CD4+ and $\mathrm{CD} 4 / \mathrm{CD} 8$ ratio with increasing age. Conversely, there were decreases in CD8 + and B cells with increasing age. There were no significant age-related changes in NK cells. However, in our cohort the majority of subjects were under 45 years of age. As such the impact of age cannot be fully elucidated and it may be worth looking at the data by various age ranges in a larger cohort to understand the effect of ageing on lymphocytes.

Contradictory findings have been reported by various studies regarding smoking and lymphocyte subsets [37-39]. Our study demonstrated no significant differences in lymphocyte subsets between smokers and non-smokers.

\section{Conclusion}

In conclusion, we have established local reference ranges for lymphocyte subsets for healthy Qatari adults in this study. The differences observed in lymphocyte subsets between our population and other studies may be the result of genetic, lifestyle and/or environmental factors, necessitating the establishment of populationbased reference ranges. Our study further confirms the gender difference in lymphocytes. The impact of age was less certain.

\section{Future perspective}

The lymphocyte references ranges are very poorly established in Qatar as well as the rest of the Arab world. In the coming decade, we hope to:

- Replicate the results in a larger cohort of the Qatari population;

- Collaborate with other researchers in the Middle East to establish reference ranges for the entire Arab population;
- Establish the effect of age on lymphocyte ranges in a larger cohort stratified by age.

Hopefully, modification of gating strategies (especially development of automated gating) over the next few 5-10 years will allow for more robust and reliable data. Development of systems where multiple parameters can be analyzed at the same time can further help improve quality of data in this field.

\section{Acknowledgements}

A Al-Thani designed this study. W Saleem performed data analysis and drafted the manuscript. A Alnaqdy assisted in designing the study and drafted the study proposal. A Al-Marwani and $\mathrm{H}$ Sharafeldin helped collect the samples. All authors read and approved the final manuscript.

\section{Financial \& competing interests disclosure}

This work was supported by a grant from Qatar University. The authors have no other relevant affiliations or financial involvement with any organization or entity with a financial interest in or financial conflict with the subject matter or materials discussed in the manuscript apart from those disclosed.

Writing assistance was utilized in the production of this manuscript. The authors would like to acknowledge support of $\mathrm{s} \equiv$ ati, from Medcommz Ltd in providing editorial support for this article. The authors wish to thank M Alkhinji and F Dadbakhash for technical assistance.

\section{Ethical conduct of research}

Hamad Medical Research Center Ethics Committee provided the ethical approval for this study. The authors state that they have obtained appropriate institutional review board approval or have followed the principles outlined in the Declaration of Helsinki for all human or animal experimental investigations. In addition, for investigations involving human subjects, informed consent has been obtained from the participants involved.

\section{Executive Summary}

- We aimed to determine the reference ranges of lymphocyte subsets in healthy Qatari adults.

- Flow cytometery was used to establish normal reference range for peripheral blood lymphocyte in 150 adults.

- The mean percentage and absolute values of the lymphocyte subsets were found to be specific to this population and markedly different from reference ranges (based on the Western population)

- Significant differences between males and females were found in the percentage and cell counts of lymphocytes

- The impact of age was less certain.

- Our study demonstrates the importance of establishing local reference ranges for each population.

\section{References}

Papers of special note have been highlighted as:

- of interest; $\bullet$ of considerable interest

1 Mccoy JP Jr, Keren DF. Current practices in clinical flow cytometry. A practice survey by the American Society of
Clinical Pathologists. Am. J. Clin. Pathol. 111, 161-168 (1999).

2 Tollerud DJ, Clark JW, Brown LM et al. The influence of age, race, and gender on peripheral blood mononuclear-cell subsets in healthy nonsmokers. J. Clin. Immunol. 9, 214-222 (1989). 
3 Santagostino A, Garbaccio G, Pistorio A et al. An Italian national multicenter study for the definition of reference ranges for normal values of peripheral blood lymphocyte subsets in healthy adults. Haematologica 84, 499-504 (1999).

4 Prince HE, Hirji K, Waldbeser LS, Plaeger-Marshall S, Kleinman S, Lanier L. Influence of racial background on the distribution of T-cell subsets and Leu 11-positive lymphocytes in healthy blood donors. Diagn. Immunol. 3 , 33-37 (1985).

5 Angadi CV. Lack of Leu-3a epitope on T-helper (CD4) lymphocytes. J. Clin. Lab. Anal. 4, 193-195 (1990).

6 Tollerud DJ, Clark JW, Brown LM et al. The effects of cigarette smoking on $\mathrm{T}$ cell subsets. A population-based survey of healthy caucasians. Am. Rev. Respir. Dis. 139(6), 1446-1451 (1989).

7 Schaberg T, Theilacker C, Nitschke OT, Lode H. Lymphocyte subsets in peripheral blood and smoking habits. Lung 175(6), 387-394 (1997).

8 Denny T, Yogev R, Gelman R et al. Lymphocyte subsets in healthy children during the first 5 years of life. JAMA 267(11), 1484-1488 (1992).

9 Erkeller-Yuksel FM, Deneys V, Yuksel B et al. Age-related changes in human blood lymphocyte subpopulations. J. Pediatr. 120(2 Pt 1), 216-222 (1992).

- Report demonstrating that a proportion of CD4 cells bearing certain markers are consistently lower in adults than in children

10 Tollerud DJ, Ildstad ST, Brown LM et al. T-cell subsets in healthy teenagers: transition to the adult phenotype. Clin. Immunol. Immunopathol. 56(1), 88-96 (1996).

11 Lee BW, Yap HK, Chew FT et al. Age- and sex-related changes in lymphocyte subpopulations of healthy Asian subjects: from birth to adulthood. Cytometry 26(1), 8-15 (1996).

- $\quad$ Flow cytometric analysis of lymphocyte subsets in 391 healthy Asian subjects, which suggested the presence of age, sex, and probable racial differences in lymphocyte subset expression in this population.

12 Reichert $\mathrm{T}$, DeBruyère $\mathrm{M}$, Deneys $\mathrm{V}$ et al. Lymphocyte subset reference ranges in adult Caucasians. Clin. Immunol. ImmunoPathol. 60(2), 190-208 (1991).

13 Rudy BJ, Wilson CM, Durako S, Moscicki AB, Muenz L, Douglas SD. Peripheral blood lymphocyte subsets in adolescents: a longitudinal analysis from the REACH project. Clin. Diagn. Lab. Immunol. 9(5), 959-965 (2002).

14 Al Qouzi A, Al Salamah A, Al Rasheed Ret al. Immunophenotyping of peripheral blood lymphocytes in Saudi men. Clin. Diagn. Lab. Immunol. 9(2), 279-281 (2002).

- Flow cytometry to establish reference ranges for lymphocytes subsets in an Saudi adult population, which demonstrated the importance of establishing national reference ranges.

15 BD Multitest ${ }^{\mathrm{TM}}$ IMK Kit 50 Tests per kit-Catalog No. 340503 (BD Biosciences).

http://www.bdbiosciences.com/ds/europe/tds/23-3602.pdf.
16 BartLett JA, Schleifer SJ, Demetrikopoulos MK et al. Immune function in healthy adolescents. Clin. Diagn. Lab. Immunol. 5(1), 105-113 (1998).

17 PetitClerc C, Wilding P. International Federation of Clinical Chemistry (IFCC), Scientific Committee, Clinical Section: the theory of reference values. Part 2. Selection of individuals for the production of reference values. J. Clin. Chem. Clin. Biochem. 22, 203-208 (1984).

18 Wayne PA. How to Define and Determine Reference Intervals in the Clinical Laboratory; Approved GuidelineSecond Edition. National Committee for Clinical Laboratory Standards. (2000). NCCLS document C28-A2

19 Dalal BI, Chhanabhai M, Horsman DE, LeHuquet J, Coupland R. Laboratory guidelines for enumerating CD4 T lymphocytes in the context of HIV/AIDS. World Health Statistics 2007 (2007). http://www.who.int/gho/ publications/world_health_statistics/whostat2007.pdf?ua=1.

20 Maini MK, Gilson RJC, Chavda N et al. Reference ranges and sources of variability of CD 4 counts in HIV seronegative women and men. Genitourin Med. 72, 27-31 (1996).

21 Peters RE, Al-Ismail S. Immunophenotyping of normal lymphocytes. Clin. Lab. Haematol. 16, 21-32 (1994).

22 Kaaba SA, Al Fadhli S, Khamis A. Reference values of lymphocyte subsets in the normal healthy adult Kuwaiti Arab population. Immunol. Lett. 81(3), 199-203 (2002).

- Flow cytometry to establish reference ranges for lymphocytes subsets in Kuwaiti adult population, which demonstrated the importance of establishing national reference ranges.

23 Chng WJ, Tan GB, Kuperan P. Establishment of adult peripheral blood lymphocyte subset reference range for an Asian population by single-platform flow cytometry: influence of age, sex, and race and comparison with other published studies. Clin. Diagn. Lab. Immunol. 11(1), 168-173 (2004).

24 Olsen NJ, Viselli SM, Fan J, Kovacs WJ. Androgens accelerate thymocyte apoptosis. Endocrinology 139, 748-752 (1998).

25 McMurray RW, Hoffman RW, Nelson W, Walker SE. Cytokine mRNA expression in the $\mathrm{B} / \mathrm{W}$ mouse model of systemic lupus erythematosus-analysis of strain, gender, and age effects. Clin. Immunol. ImmunoPathol. 84, 260-268 (1997).

26 Grossman C. Possible underlying mechanisms of sexual dimorphism in the immune response, fact and hypothesis. J. Steroid Biochem. 34, 241-251 (1989).

- Review which examines factors responsible for immunological dimorphism in males versus females including hormonal factors, genetic components and so on.

27 Didier ES, Sugimoto C, Bowers LC, Khan IA, Kuroda MJ. Immune correlates of aging in outdoor-housed captive rhesus macaques (Macaca mulatta). Immun. Ageing 9(1), 25 (2012).

28 Shaw AC, Joshi S, Greenwood H, Panda A, Lord JM. Aging of the innate immune system. Curr. Opin. Immunol. 22(4), 507-513 (2010).

29 Kovacs EJ, Palmer JL, Fortin CF, Fulop T Jr, Goldstein DR, Linton PJ. Aging and innate immunity in the mouse: impact 
of intrinsic and extrinsic factors. Trends Immunol. 30(7), 319-324 (2009).

30 Panda A, Arjona A, Sapey E et al. Human innate immunosenescence: causes and consequences for immunity in old age. Trends Immunol. 30 (7), 325-333 (2009).

- Interesting review which explores human immunosenescence in the innate immune system focusing on effects of age.

31 Gruver AL, Hudson LL, Sempowski GD. Immunosenescence of ageing. J. Pathol. 211(2), 144-156 (2007).

32 Yan J, Greer JM, Hull R et al. The effect of ageing on human lymphocyte subsets: comparison of males and females. Immun. Ageing 7, (2010).

- Study demonstrating the effect of ageing, which was significantly greater for men than for women for CD8 + T cells and CD3+ effector memory cells.

33 Martínez-Taboada V, Bartolomé MJ, Amado JA et al. Changes in peripheral blood lymphocyte subsets in elderly subjects are associated with an impaired function of the hypothalamicpituitary-adrenal axis. Mech. Ageing Dev. 123(11), 1477-1486 (2002).

34 Banerjee M, Sanderson JD, Spencer J, Dunn-Walters DK. Immunohistochemical analysis of ageing human $\mathrm{B}$ and $\mathrm{T}$ cell populations reveals an age-related decline of CD8 T cells in spleen but not gut-associated lymphoid tissue (GALT). Mech. Ageing Dev. 115(1-2), 85-99 (2000).

35 Shahabuddin S. Quantitative differences in CD8+ lymphocytes, CD4/CD8 ratio, NK cells, and HLA-DR+activated T cells of racially different male populations. Clin. Immunol. ImmunoPathol. 75, 168-170 (1995).

36 Wiener D, Shah S, Malone J, Lowell N, Lowitt S, Rowlands DT Jr. Multiparametric analysis of peripheral blood in the normal paediatric population by flow cytometry. J. Clin. Lab. Anal. 4175-4179 (1990).

37 Mehta H, Nazzal K, Sadikot RT. Cigarette smoking and innate immunity. Inflamm. Res. 57, 497-503 (2008).

38 Uppal SS, Verma S, Dhot PS. Normal values of CD4 and CD8 lymphocyte subsets in healthy Indian adults and the effects of sex, age, ethnicity, and smoking. Cytometry B Clin. Cytom. 52(1), 32-36 (2003).

- Study provided normal ranges of absolute and percentage values of CD4 and CD8 T-lymphocyte subsets and the ratio of CD4 to CD8 in normal Indian adults, which were also stratified by age, sex, ethnicity and smoking status.

39 Santosh Kumar SC. Comparison of CD4 lymphocyte subset count between smokers and non-smokers. Int. J. Adv. Res. 5(S1), 41-43 (2014).

40 Al-Mawali A, Pinto AD, Al Busaidi R, Al-Zakwani I. Lymphocyte subsets: reference ranges in an age- and genderbalanced population of Omani healthy adults. Cytometry 83(8), 739-744 (2013)

41 Tsegaye A, Messele T, Tilahun T et al. Immunohematological reference ranges for adult Ethiopians. Clin. Diagn. Lab. Immunol. 6, 410-414 (1999).

42 Bisset LR, Lung TL, Kaelin M, Ludwig E, Dubs RW. Reference values for peripheral blood lymphocyte phenotypes applicable to the healthy adult population in Switzerland. Eur. J. Haematol. 72(3), 203-212 (2004).

43 Wong WS, Lo AW, Siu LP et al. Reference ranges for lymphocyte subsets among healthy Hong Kong Chinese adults by single-platform flow cytometry. Clin. Vaccine Immunol. 20(4), 602-606 (2013). 